Fastabiq: Jurnal Studi Islam

ISSN 2723-0228

Volume 1 Nomor 1 Juni 2020

Halaman 61-79

\title{
KONSTRUKSI AKAD MUDHÂRABAH DALAM FATWA DEWAN SYARIAH NASIONAL-MAJELIS ULAMA INDONESIA NOMOR: 03/DSN-MUI/IV/2000 TENTANG DEPOSITO
}

\author{
Panji Adam Agus Putra \\ Fakultas Syariah Universitas Islam Bandung \\ panjiadam06@gmail.com
}

\begin{abstract}
Deposits in Islamic banks are investment funds based on mudhârabah agreements or other contracts that are not in conflict with Islamic principles. This is stated in the DSN-MUI fatwa No: 03 / DSN-MUI / IV / 2000 Concerning Deposits, where the Islamic bank acts as the fund manager and the customer is an investor. In the level of implementation, the fund manager (mudhârib) re-invests or re-mudhârabah, then there is a multi-level mudhârabah contract which the islamic jurist has debated its legal status. The research method based on the normative juridical approach with the specification used is analytical descriptive and the data collection method used is literature study. Takyif figh and contract construction in sharia deposits, according to the author that the contract used in the implementation of the National Sharia Council No: 03 / DSN-MUI / IV / 2000 Concerning Deposits is mudhârib yudhârib contract; mudhârib al-wasith or commonly called mudhârabah birthday. In this case the Islamic bank in addition to being domiciled as mudhrib (in the first mudhârabah contract), the Islamic bank was also at the same time as shâhib al-māl (in the second mudhârabah contract). Based on the opinion of the rajj (superior) among the scholars, the law of carrying out a multilevel mudhârabah agreement or commonly referred to as mudhârib yudhârib (re-mudhârbah) is permissible based on two considerations, namely consideration of 'urf / habit (in this case the habits in the Islamic financial institutions) ) and the concept of absolute mudhârabah.
\end{abstract}

Keywords: Mudhârabah Contract, Deposit, DSN-MUI Fatwa

\begin{abstract}
Abstrak
Deposito di bank syariah merupakan investasi dana berdasarkan akad mudhârabah atau akad lain yang tidak bertentangan dengan prinsip syariah. Hal ini sebagaimana tertuang dalam fatwa DSN-MUI No: 03/DSN-MUI/IV/2000 Tentang Deposito, dimana pihak bank syariah bertindak sebagai pengelola dana dan nasabah berkedudukan sebagai investor. Dalam tataran implementasinya pihak pengelola dana (mudhârib) melakukan investasi ulang atau ulang mudhârabah, maka terjadi di dalamnya akad mudhârabah bertingkat yang oleh para ulama fikih diperdebatkan status hukumnya. Metode penelitian yang dilakukan berdasarkan pendekatan secara yuridis normatif dengan spefisikasi digunakan adalah deskriptif analitis dan Metode pengumpulan data yang dipergunakan adalah studi kepustakaan. Takyif fikih dan kontruksi akad dalam deposito syariah, menurut penulis bahwa akad yang digunakan dalam implementasi Dewan Syari'ah Nasional No: 03/DSN-MUI/IV/2000 Tentang Deposito adalah akad mudhârib yudhârib; mudhârib al-wasîth atau biasa disebut juga ulang mudhârabah. Dalam hal ini pihak bank syariah selain berkedudukan sebagai mudhârib (pada akad mudhârabah pertama), bank syariah pun sekaligus berkedudukan sebagai shâhib al-mâl (pada akad mudhârabah kedua). Berdasarkan pendapat râjih(unggul) di antara para ulama, maka hukum melakukan akad mudhârabah bertingkat atau yang biasa disebut dengan istilah mudhârib yudhârib (ulang mudhârbah) adalah boleh berdasarkan dua pertimbangan, yaitu pertimbangan 'urf/kebiasaan (dalam hal ini kebiasaan di lembaga keuangan syraiah) dan konsep mudhârabah mutlak.
\end{abstract}

Kata Kunci: Akad Mudhârabah, Deposito, Fatwa DSN-MUI

\section{PENDAHULUAN}

Pasal 3 Undang-Undang Nomor 10 Tahun 1998 tentang Perbankan menjelaskan bahwa fungsi utama perbankan Indonesia (baik konvensional maupun syariah) adalah sebagai lembaga 


\section{Fastabiq: Jurnal Studi Islam}

ISSN 2723-0228

Volume 1 Nomor 1 Juni 2020

perantara (intermediary institution) yang menghimpun dana dan menyalurkan dana masyarakat. Dana masyarakat yang disimpan dalam bentuk rekening giro, deposito dan/atau tabungan kemudian dihimpun dan dikelola oleh bank, simpanan yang dipercayakan oleh masyarakat kepada bank tersebut kemudian disalurkan oleh bank dalam bentuk fasilitas pembiayaan kepada masyarakat yang membutuhkan dana. ${ }^{1}$

Khusus terkait bank syariah, penghimpunan dana pada bank syariah tidak terbatas pada prinsip simpanan, tetapi dapat juga digunakan prinsip investasi. Akad yang sesuai dengan prinsip ini salah satunya adalah akad mudhârabah. Tujuan dari akad mudhârabah adalah kerja sama antara pemilik dana (shâhib al-mâl) dan pengelola dana (mudhârib), dalam hal ini adalah pihak bank syariah. Dalam praktiknya, bank-bank syariah memiliki rekening investasi umum yang berfungsi seperti deposito berjangka pada bank konvensional. Berbeda dengan bank konvensional, bank syariah menerapkan prinsip syariah di dalam produknya, termasuk dalam hal ini produk investasi yang berbentuk deposito. $^{2}$

Industri perbankan syariah dalam bersaing dengan perbankan konvensional telah melakukan inovasi produk-produk akad yang kompetitif seperti lahirnya produk-produk pembiayaan berbasis akad-akad baru dalam fikih muamalah seperti IMBT, IMFZ, MMQ dan sebagainya. Itu karena, jika dikaji lebih jauh, transformasi fikih muamalah ke dalam akad perbankan syariah melalui produkproduk akad perbankan yang ditawarkan kepada nasabah telah mengalami pergeseran paradigma dari fikih muamalah klasik menuju fikih kontemporer. ${ }^{3}$

Menurut Pasal 1 angka 12 Undang-Undang Nomor 21 Tahun 2008 tentang Perbankan Syariah, yang dimaksud dengan prinsip syariah adalah prinsip hukum Islam dalam kegiatan perbankan berdasarkan fatwa yang dikeluarkan oleh lembaga yang memiliki kewenangan dalam penetapan fatwa di bidang syariah.

Fatwa, dalam praktik perbankan syariah, memiliki peran sebagai pedoman dalam mengimplementasikan prinsip-prinsip syariah. Dewan Syariah Nasional-Majelis Ulama Indonesia (DSN-MUI) adalah lembaga yang memiliki kewenangan dalam membuat serta meneruskan fatwafatwa di bidang ekonomi dan bisnis syariah. Salah satu fatwa yang berkaitan dengan produk penghimpunan dana adalah fatwa DSN-MUI No: 03/DSN-MUI/IV/2000 Tentang Deposito.

Dewan Syariah Nasional MUI, dalam hal mengelola dana nasabah Deposito, telah mengeluarkan fatwa yang menyatakan bahwa deposito yang dibenarkan adalah deposito yang berdasarkan akad mudhârabah. Dimana pihak bank syariah bertindak sebagai pengelola dana dan nasabah berkedudukan sebagai investor. Dalam kapasitasnya sebagai muḍhārib, bank syariah dan BMT dapat melakukan berbagai macam usaha yang tidak bertentangan dengan prinsip syariah dan mengembangkannya, ${ }^{4}$ termasuk di dalam melakukan akad mudhârabah dengan pihak ketiga.

Pihak pengelola dana (mudhârib), dalam konteks fikih, ketika melakukan investasi ulang atau ulang mudhârabah, maka terjadi di dalamnya akad mudhârabah bertingkat. Para ulama fikih berbeda pendapat mengenai keabsahan akad mudhârabah bertingkat tersebut, yang saat ini terimplementasikan dalam produk deposito syariah berdasarkan akad mudhârabah berdasarkan fatwa DSN-MUI No: 03/DSN-MUI/IV/2000 Tentang Deposito. 


\section{Fastabiq: Jurnal Studi Islam}

ISSN 2723-0228

Volume 1 Nomor 1 Juni 2020

Tujuan penelitian ini adalah untuk mengetahui bagaimana konstruksi akad mudhârabah dalam produk deposito syariah berdasarkan fatwa DSN-MUI No: 03/DSN-MUI/IV/2000 Tentang Deposito; serta menganalisis takyif fikih dalam implementasi fatwa tersebut.

Penelitian ini diharapkan memberikan manfaat secara teoritis berupa kontribusi pemikiran bagi pengembangan khazanah keilmuan khususnya di bidang hukum ekonomi syariah. Adapun manfaat secara praktik, penelitian ini diharapkan menjadi bahan kajian dalam membuat regulasi baik dalam bentuk peraturan perundang-undangan atau fatwa serta menjadi bahan diskusi ilmiah dikalangan para akademisi, khususnya para pegiat hukum ekonomi syariah. Dan diharapkan pula secara praktis sebagai bahan pedoman bagi lembaga keuangan syariah dalan mengimplemantasikan prinsip-prinsip syariah.

\section{METODE PENELITIAN}

Metode penelitian yang dilakukan berdasarkan pendekatan secara yuridis normatif, yaitu dengan mengkaji atau menganalisis data sekunder yang berupa bahan-bahan hukum sekunder dengan memahami hukum sebagai perangkat peraturan atau norma positif di dalam perundangundangan yang berlaku, jadi penelitian ini dipahami sebagai penelitian kepustakaan, yaitu penelitian terhadap bahan sekunder. ${ }^{5}$

Spesifikasi penelitian yang digunakan adalah deskriptif analitis, yaitu penelitian untuk menggambarkan masalah yang ada pada masa sekarang (masalah yang aktual), dengan mengumpulkan data, menyusun, mengklasifikasikan, menganalisis, dan menginterpretasikan. Deskriptif bertujuan memaparkan data hasil pengamatan tanpa pengujian hipotesis-hipotesis. ${ }^{6}$

Jenis data yang dipergunakan dalam peneitian ini, yaitu data sekunder, yakni norma hukum berupa fatwa, yaitu Fatwa Dewan Syari'ah Nasional-Majelis Ulama Indonesia (DSN-MUI) Nomor: 03/DSN-MUI/IV/2000 tentang Deposito.

Metode pengumpulan data yang dipergunakan adalah studi kepustakaan, yaitu dengan mengkaji dan menganalisis Fatwa Dewan Syari'ah Nasional No: 03/DSN-MUI/IV/2000 Tentang Deposito. Metode analisis data yang digunakan dalam penelitian ini adalah metode kualitatif.

Analisis terhadap data sekunder yang bersifat kualitatif tersebut dilakukan dengan cara berlandaskan pada teori hukum ataupun doktrin hukum yang terdapat pada kerangka pikir, kemudian diterapkan secara deduktif terhadap fokus permasalahan.

\section{PEMBAHASAN}

\section{Konsep dan Regulasi Deposito Syariah}

Deposito sebagai salah satu produk perbankan dalam perbankan syariah menggunakan skema mudhârabah. Hal ini sejalan dengan tujuan dari nasabah menggunakan instrumen deposito yakni sebagai sarana investasi dalam upaya memperoleh keuntungan.

Menurut Khatibul Umam, Deposito merupakan produk dari bank yang memang ditujukan untuk kepentingan investasi dalam bentuk surat-surat berharga, sehingga dalam perbankan syariah 


\section{Fastabiq: Jurnal Studi Islam}

ISSN 2723-0228

Volume 1 Nomor 1 Juni 2020

akan memakai prinsip mudhârabah. Berbeda dengan perbankan konvensional yang memberikan imbalan berupa bunga bagi nasabah deposan, maka dalam perbankan syatiah imbalan yang diberikan kepada nasabah deposan adalah bagi hasil (profit sharing) sebesar nisbah yang telah disepakati di awal akad. ${ }^{7}$

Dalam Pasal 1 angka 22 Undang-Undang Nomor 21 Tahun 2008 tentang Perbankan Syariah, Deposito didefinisikan sebagai investasi dana berdasarkan akad mudhârabah atau akad lain yang tidak bertentangan dengan prinsip syariah yang penarikannya hanya dapat dilakukan pada waktu tertentu berdasarkan akad antara nasabah penyimpan dan Bank Syariah dan/atau UUS.

Dalam fatwa Dewan Syari'ah Nasional No: 03/DSN-MUI/IV/2000 Tentang Deposito didefinisikan sebagai deposito, yaitu simpanan dana berjangka yang penarikannya hanya dapat dilakukan pada waktu tertentu berdasarkan perjanjian nasabah penyimpan dengan bank.

Landasan syar'i deposito mudhârabah seperti diterangkan oleh fatwa Dewan Syari'ah Nasional No: 03/DSN-MUI/IV/2000 Tentang Deposito didefinisikan sebagai deposito, di antaranya adalah: Q.S al-Baqarah (2): 198 dan 283I serta Q.S al-Maidah (5): 1. Secara syar'i, deposito itu ada dua macam; deposito yang tidak dibenarkan syariah, yaitu deposito yang berdasarkan perhitungan bunga; dan deposito yang dibenarkan yaitu deposito yang berdasarkan prinsip mudhârabah.

Lebih lanjut dalam fatwa tersebut dijelaskan mengenai ketentuan umum deposito dengan skema akad mudhârabah sebagai berikut: (1) Dalam transaksi ini nasabah bertindak sebagai shâhib al-mâl atau pemilik dana, dan bank bertindak sebagai mudhârib atau pengelola dana; (2) Dalam kapasitasnya sebagai mudharib, bank dapat melakukan berbagai macam usaha yang tidak bertentangan dengan prinsip syari'ah dan mengembangkannya, termasuk di dalamnya mudharabah dengan pihak lain; (3) Modal harus dinyatakan dengan jumlahnya, dalam bentuk tunai dan bukan piutang; (4) Pembagian keuntungan harus dinyatakan dalam bentuk nisbah dan dituangkan dalam akad pembukaan rekening; (5) Bank sebagai mudharib menutup biaya operasional deposito dengan menggunakan nisbah keuntungan yang menjadi haknya; dan (6) Bank tidak diperkenankan untuk mengurangi nisbah keuntungan nasabah tanpa persetujuan yang bersangkutan.

Sejalan dengan fatwa DSN-MUI di atas, ketentuan dalam Pasal 5 Peraturan Bank Indonesia Nomor 7/46/PBI/2005 menetapkan persyaratan paling kurang dalam kegiatan penghimpunan dana dalam bentuk deposito berdasarkan mudhârabah, sebagai berikut: (1) Bank syariah bertindak sebagai pengelola dana dan nasabah bertindak sebagai pemilik dana; (2) Dana disetor penuh kepada bank syariah dan dinyatakan dalam jumlah nominal; (3) Pembagian keuntungan dari pengelolaan dana investasi dinyatakan dalam bentuk nisbah; (4) Bank syariah sebagai mudhârib menutup biaya operasional deposito dengan menggunakan nisbah keuntungan yang menjadi haknya; (5) Bank syariah tidak diperbolehkan mengurangi bagian keuntungan nasabah tanpa persetujuan nasabah yang bersangkutan; dan (6) Bank syariah tidak menjamin dana nasabah, kecuali diatur berbeda dalam perundang-undangan yang berlaku.

Begitu pula dalam ketentuan mengenai persyaratan paling kurang kegiatan penghimpunan dana dalam bentuk deposito atas dasar akad mudhârabah tersebut, diatur kembali dalam Surat Edaran Bank Indonesia Nomor 10/14/DPbS tanggal 17 Maret 2008 sebagai berikut: (a) bank bertidak 


\section{Fastabiq: Jurnal Studi Islam \\ ISSN 2723-0228}

Volume 1 Nomor 1 Juni 2020

sebagai pengelola dana (mudharib) dan nasabah bertindak sebagai pemilik dana (shâhib al-mân); (b) pengelola dana oleh bank dapat dilakukan sesuai batasan-batasan yang ditetapkan oleh pemilik dana (mudharabah muqayyadah) atau dilakukan dengan tanpa batasan-batasan dari pemilik dana (mudharabah muqayyadah); (c) Bank wajib menjelaskan kepada nasabah mengenai karakteristik produk, serta hak dan kewajiban nasabah sebagaimana diatur dalam ketentuan Bank Indonesia mengenai transparansi informasi produk bank dan penggunaan data pribadi nasabah; (d) Bank dan nasabah wajib menuangkan kesepakatan atas pembukaan dan penggunaan produk deposito atas dasar akad mudharabah, dalam bentuk perjanjian tertulis; (e) dalam akad mudharabah muqayyadah harus dinyatakan secara jelas syarat-syarat dan batasan tertentu yang ditentukan oleh nasabah: (f) pembagian keuntungan dinyatakan dalam bentuk nisbah yang disepakati; (g) penarikan dana oleh nasabah hanya dapat dilakukan sesuai waktu yang disepakati; (h) bank dapat membebankan kepada nasabah biaya administrasi berupa biaya-biaya yang terkait langsung dengan biaya pengelolaan rekening antara lain biaya materai, cetak laporan transaksi dan saldo rekening, pembukaan rekening; dan (i) Bank tidak diperbolehkan mengurangi bagian keuntungan nasabah tanpa persetujuan nasabah yang bersangkutan.

Inti dari sejumlah ketentuan deposito mudhârabah, baik yang difatwakan oleh DSN-MUI maupun yang ditetapkan oleh BI meliputi masalah posisi pemilik dana, pengelola dana, aturan dan cara pengelolaan dana, transaksi pembagian keuntungan, penarikan dana oleh pemilik, dan biaya operasional. Ketentuan-ketentuan itu dapat diformulasikan sebagai berikut: ${ }^{8}$ (1) Dalam deposito mudhârabah, pemilik dana bertindak sebagai nasabah (shâhib al-mâl) sementara bank sebagai pengelola dana (mudârib) dan dana disetor ke bank secara penuh serta dinyatakan dalam jumlah nominal; (2) Pembuatan transaksi kesepakatan antara pihak nasabah dan bank meliputi; batasan atau tanpa batasan pengelolaan seperti jenis atau macam usaha yang dimintakan oleh nasabah, presentasi pembagian keuntungan, dan waktu penarikan dana oleh nasabah; (3) Bank tidak diperkenankan mengurangi bagian keuntungan nasabah tanpa persetujuan nasabah yang bersangkutan; dan (4) Bank diperkenankan membebankan biaya administrasi kepada nasabah, berupa biaya yang terkait langsung dengan pengelolaan rekening seperti biaya materai, cetak laporan transaksi dan saldo rekening, pembukaan dan penutupan rekening.

Berdasarkan penjelasan di atas dapat diketahui bahwa dalam perbankan syariah salah satu instrumen penghimpunan dana dari masyarakat secara langsung adalah depositi (time deposit). Berbeda dengan bank konvensional yang menggunakan bunga sebagai kontraprestasi bagi nasabah, maka dalam perbankan syariah menggunakan dua prinsip perjanjian Islam yang didalamnya diyakini tidak mengandung unsur riba, maysir, gharar, yaitu prinsip titipan (wadi'ah) dan prinsip bagi hasil (mudhârabah).

Apabila dibandingkan dengan deposito yang menggunakan prinsip bunga tetap, jauh berbeda dengan deposito yang menggunakan prinsip tanpa bunga. Dalam sistem bunga, nasabah pemilik deposito akan menerima bunga tertentu secara tetap dan periodik, tanpa mengindahkan usaha yang dijalankan oleh pihak bank syariah, baik merugi maupun untung. Dalam deposito mudhârabah, besaran return yang akan diterima bank, yakni nisbah atau presentase tertentu dari total hasil usaha 


\section{Fastabiq: Jurnal Studi Islam}

ISSN 2723-0228

Volume 1 Nomor 1 Juni 2020

yang didapatkan oleh pihak bank. Pihak bank selaku mudharib tidak memiliki kewajiban secara tetap untuk memberikan return dalam besaran tertentu, tetapi bergantung pada hasil usaha yang dijalankan. Akad ini lebih tepat digunakan karena sesuai dengan karakteristik usaha yang memiliki potensi untung rugi. ${ }^{9}$

Mekanisme penghimpunan dana oleh bank syariah melalui produk deposito biasanya didasarkan pada akad mudhârabah muthlaqah, yaitu akad mudhârabah yang memberikan kebebasan kepada mudhârib (bank) untuk memroduktifkan dana yang ada yang meliputi jenis usaha dan ruang lingkupnya. Sedangkan dana yang diperoleh akan dilempar/disalurkan kepada masyarakat dengan mendasarkan pada akad mudhârabah muqayyadah sehingga memudahkan bank dalam proses monitoring. ${ }^{10}$

Nasabah selaku deposan akan mendapatkan kontraprestasi berupa bagi hasil yang besarannya sesuai dengan nisbah yang ditentukan diawal akad. Dengan menggunakan akad mudhârabah nasabah juga menanggung risiko tidak mendapatkan keuntungan, bahkan akan hilang sebagian uang yang disimpannya jika usaha yang didanai mengalami kerugian.

\section{Akad Mudhârabah Dalam Perspektif Fikih Muamalah}

Mudhârabah berasal dari kata dharb, yang artinya memukul atau berjalan. Pengertian memukul atau berjalan ini lebih tepatnya adalah proses seseorang menggerakan kakinya dalam menjalankan usahanya. ${ }^{11}$ Mudhârabah disebut juga qirâdh. Mudhârabah merupakan bahasa penduduk Irak, sedangkan menurut bahasa penduduk Hijaz disebut dengan istilah qirâdh. ${ }^{12}$

Menurut Neneng Nurhasanah ${ }^{13}$, al-qirâdh, al-muqâradhah, dan al-mudhârabah adalah satu makna, yaitu penyerahan harta (modal) terhadap seseorang untuk diperniagakan (digolangkan), sedangkan keuntungannya dibagikan di antara mereka (pemodal dan yang diberi modal). Qirâdh, dengan huruf Qaf yang dikasrahkan diambil dari kata al-qardhu yang artinya al-qath'u (potongan). Sebab pemilik memberikan potongan dari hartanya untuk diberikan kepada pengusaha agar menggolangkan harta tersebut, dan pengusaha akan memberikan potongan dari laba yang diperoleh. Qirâdh bisa diambil dari kata muqâradhah yang berarti al-musâwah (kesamaan), sebab pemilik modal dan pengusaha memiliki hak yang sama terhadap laba.

Orang Irak menyebutkanya dengan istilah mudhârabah, sebab setiap orang yang melakukan akad memiliki bagian dari laba, atau pengusaha harus mengadakan perjalanan dalam mengusahakan harta modal tersebut. Perjalanan tersebut dinamakan dharban fî al-safar. ${ }^{14}$

Adapun istilah mudhârabah atau qirâdh dikemukakan oleh para ulama dengan redaksi yang berbeda-beda, di antaranya sebagai berikut:

a. Menurut mayoritas fuqaha, mudhârabah ialah:"

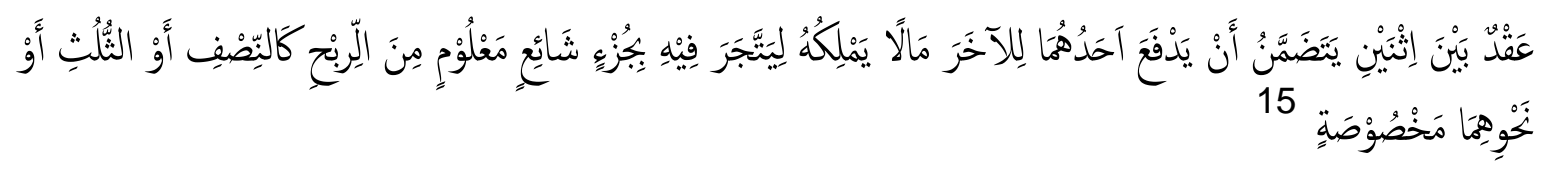




\section{Fastabiq: Jurnal Studi Islam}

ISSN 2723-0228

Volume 1 Nomor 1 Juni 2020

"Akad antara dua pihak yang saling menanggung, salah satu pihak menyerahkan hartanya kepada pihak lain untuk diperdagangkan dengan bagian yang telah ditentukan dari keuntungan, seperti setengah atau sepertiga dengan syarat-syarat yang telah ditentukan".

b. Menurut Ulama Hanafiyah akad mudhârabah ialah:

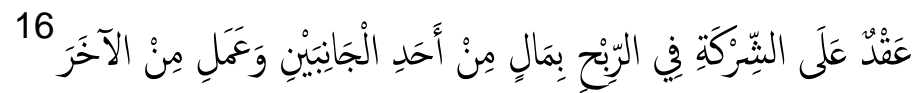

"Akad perkongsian dalam hal keuntungan, satu pihak sebagai pemilik harta (modal) dan pihak yang lain pemilik jasa".

c. Menurut Ulama Malikiyah akad mudhârabah ialah:

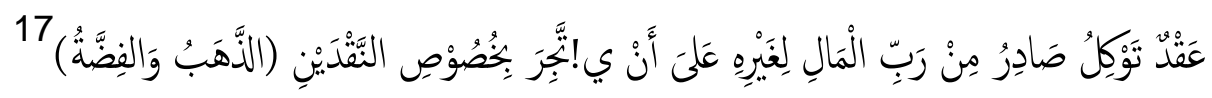

"Akad perwakilan, dimana pemilik harta mengeluarkan hartanya kepada yang lain untuk diperdagangkan dengan pembayaran yang ditentukan (mas dan perak).

d. Menurut Ulama Syafi'iyah akad mudhârabah ialah:

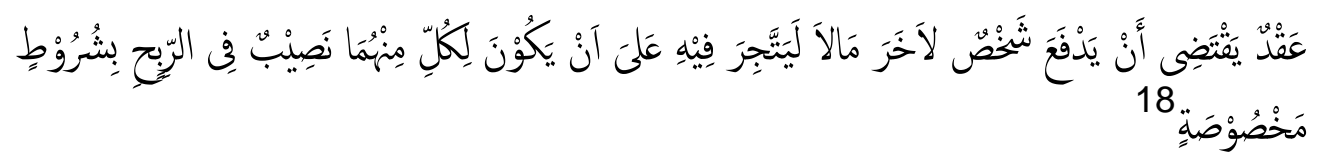

"Akad yang menentukan seseorang menyerahkan hartanya kepada pihak lain untuk diperdagangkan dan keduanya mendapat bagian dari keuntungan berdasarkan kesepakatan".

Menurut ulama Hanabilah akad mudhârabah ialah:

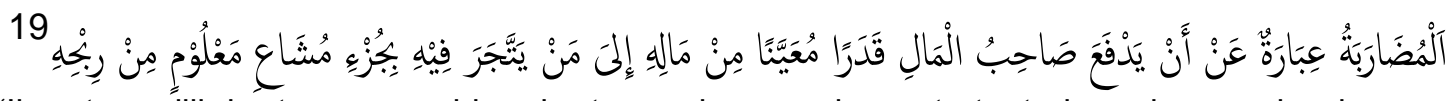

"Ibarat pemilik harta menyerahkan hartanya dengan ukuran tertentu kepada yang berdagang bagian dari keuntungan yang diketahui".

e. Menurut Kompilasi Hukum Ekonomi Syariah (KHES) Pasal 20 ayat (6):

Mudhârabah adalah kerja sama antara pemilik dana atau penanam modal dan pengelola modal untuk melakukan usaha tertentu dengan pembagian keuntungan berdasarkan nisbah.

Berdasarkan uraian para ulama di atas, dapat disimpulkan bahwa akad Mudhârabah adalah akad kerja sama usaha di antara dua pihak dimana pihak pertama (shâhib al-mâl) menyediakan seluruh (100\%) modal, sedangkan pihal lainnya menjadi pengelola. Secara mudhârabah, keuntungan usaha dibagi menurut kesepakan yang dituangkan dalam kontrak. Apabila usaha tersebut mengalami kerugian, maka kerugian tersebut ditanggung oleh pemilik modal selama kerugian itu bukan akibat kelalaian si pengelola. Seandainya kerugian itu diakibatkan karena kecurangan atau kelalaian si pengelola, maka si pengelola harus bertanggung jawab atas kerugian tersebut. ${ }^{20}$

Landasan yuridis mengenai kebolehannya akad mudhârabah terdapat dalam Al-Qur'ân, hadis, ijmâ' (consensus) dan qiyâs (analogy). Dibawah ini, penulis akan menguarai landasan yuridis mengenai kebolehan akad mudhârabah.

Dalam al-Quran surah al-Muzammil (73): 20 Allah Swt berfirman:

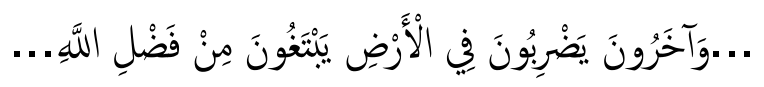

KONSTRUKSI AKAD MUDHÂRABAH DALAM FATWA DEWAN SYARIAH NASIONAL-MAJELIS ULAMA INDONESIA NOMOR: 03/DSN-MUI/IV/2O0O TENTANG DEPOSITO 


\section{Fastabiq: Jurnal Studi Islam}

ISSN 2723-0228

Volume 1 Nomor 1 Juni 2020

“...(Di antara kamu ada) orang-orang yang berjalan di muka bumi mencari sebagian karunia Allah.

Penafsiran terhadap kalimat yadhribûna fî al-Ardh adalah bahwa mereka melakukan perjalanan untuk perniagaan. ${ }^{21}$ Menurut Wahbah al-Zuhaili ${ }^{22}$, ayat ini menjelaskan tentang disyariatkannya transaksi dengan menggunakan akad mudhârabah. Yang dimaksud dengan almudharib adalah orang yang berjalan (bepergian) di muka bumi untuk mencari karunia Allah azza wa jalla, sebagaimana firman-Nya dalam Surah al-Jumu'ah (62) ayat 10: "Apabila shalat telah ditunaikan, maka bertebaranlah di muka bumi dan carilah karunia Allah dan ingatlah Allah sebanyak-banyaknya agar kamu mendapatkan kesuksesan".

Adapun hadis Nabi yang menjelaskan mengenai kebasahan akad mudhârabah di antaranya adalah sebagai berikut:

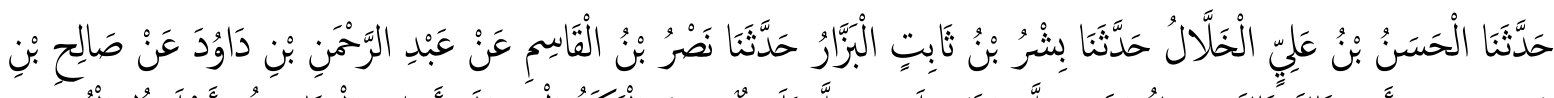

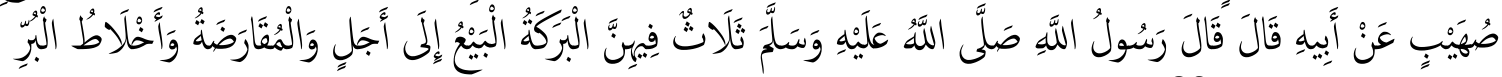

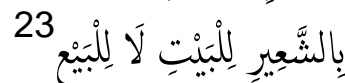

Telah menceritakan kepada kami Al Hasan bin Ali Al Khallal berkata, telah menceritakan kepada kami Bisyr bin Tsabit Al Bazzar berkata, telah menceritakan kepada kami Nashr bin Al Qasim dari 'Abdurrahman bin Dawud dari Shalih bin Shuhaib dari Bapaknya ia berkata, "Rasulullah shallallahu 'alaihi wasallam bersabda: "Tiga hal yang di dalamnya terdapat barakah; jual beli yang memberi tempo, peminjaman, dan campuran gandum dengan jelai untuk di konsumsi orang-orang rumah bukan untuk dijual."

Kesepakatan ulama mengenai bolehnya mudhârabah dikutip dari Dr. Wahbah al-Zuhaili dalam kitabnya al-Fiqh al-Islâmî wa Adillatuh sebagai berikut.

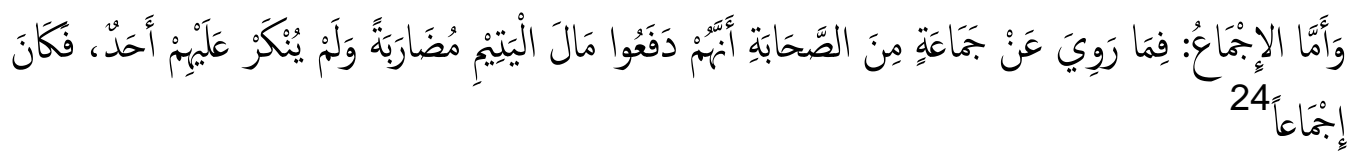

Diriwayatkan bahwa sejumlah sahabat melakukan mudhârabah dengan menggunakan harta anak yatim sebagai modal dan tidak ada seorang pun dari mereka (para sahabat) yang menyanggah ataupun menolaknya, dan otomatis hal tersebut menjadi sebuah konsensus.

Selanjutnya, Wahbah al-Zuhaili menjelaskan mengenai kebolehan akad mudhârabah dengan metode qiyâs sebagai berikut:

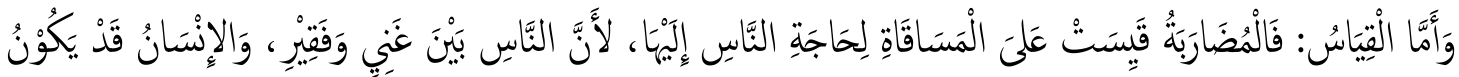

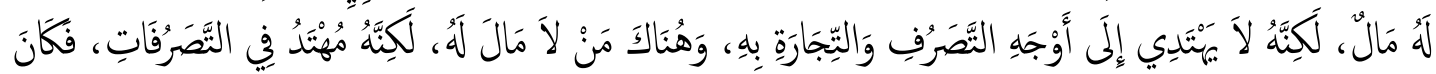

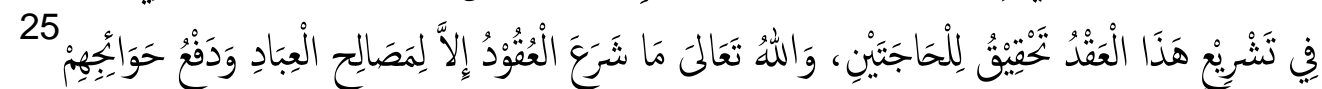

Mudhârabah dianalogikan kepada akad musâqât_untuk memenuhi kebutuhan manusia, karena diantara manusia ada yang kaya dan ada yang miskin, ada yang memiliki modal (harta) akan tetapi tidak memiliki keterampilan untuk berniaga dan mengembangkan hartanya, di lain pihak ada orang yang tidak memiliki modal, akan tetapi memiliki keterampilan untuk berniaga dan mengembangkan harta, maka akan ini disyariatkan berfungsi untuk memenuhi kebutuhan manusia. Dan Allah Swt tidaklah mensyariatkan suatu akad kecuali untuk kemaslahatan manusia dan memenuhi kebutuhannya" 


\section{Fastabiq: Jurnal Studi Islam}

ISSN 2723-0228

Volume 1 Nomor 1 Juni 2020

Sebagaimana yang sudah ketahui bahwa dalam suatu perbuatan hukum terdapat unsur-unsur yang harus dipenuhi agar perbuatan tersebut bisa dikatakan sah. Begitu pun dengan akad mudhârabah, ada unsur-unsur yang harus dipenuhi. Unsur-unsur tersebut adalah rukun. Mudhârabah dikatakan sah apabila terpenuhi rukun-rukunnya dan masing-masing rukun tersebut memerlukan syarat yang juga harus terpenuhi. Rukun mudhârabah menurut jumhur ulama adalah: (1) pihak-pihak yang melakukan akad, yaitu shâhib al-mâl (investor) dan mudhârib (pengelola dana); (2) ma'qûd, yaitu modal (ra's al-mâl), usaha (al-'amal) dan keuntungan (al-ribhh); dan (3) pernyataan atau shîghat berupa ijab/penawaran dan kabul/penerimaan. ${ }^{26}$

Adapun mengenai syarat-syarat pada akad mudhârabah adalah sebagai berikut: (1) pihakpihak yang melakukan akad mudhârabah dipersyaratkan memiliki kemampuan (cakap hukum/ahliyah al-wujûb wa al-'ada) untuk mewakilkan/memberikan kuasa (bagi shâhib al-mâl) dan menerima perwakilan/kuasa (bagi mudhârib) karena dalam akad mudhârabah terkandung akad wakâlah/kuasa, yaitu mudhârib melakukan usaha (bisnis) atas dasar kuasa dari shâhib al-mâl.Mudhârabah boleh dilakukan antara muslim dan nonmuslim (dzimmi atau musta'min) di negara muslim. Dalam bisnis, syarat yang utama bagi mudhârib (pelaku usaha) harus memiliki kemampuan, keahlian, dan keterampilan usaha sehingga mampu mengembangkan modal usaha; (2) ra's al-mâl (modal usaha) dalam akad mudhârabah harus memenuhi syarat-syarat sebagai berikut: (a) modal harus berupa alat tukar (nuqûd/uang), bukan barang; (b) modal harus diketahui dan terkukur; (c) modal harus tunai (bukan dalam bentuk piutang); dan modal harus dapat diserahkan dari shâhib al-mâl kepada mudhârib. ${ }^{27}$

Para ulama membagi akad mudhârabah menjadi 2 (dua) jenis, pertama, mudhârabah muthlâqah (investasi tidak terikat), yaitu mudhârabah yang jangkauannya luas. Transaksi ini tidak dibatasi oleh spesifikasi jenis usaha, waktu, dan wilayah bisnis. Di sini shâhib al-mâl memberikan keleluasaan kepada mudhârib untuk melakukan usaha sesuai dengan kehendaknya, tetapi sejalan dengan prinsip syariah, dengan modal yang diberikan kepadanya. Pada usaha perbankan syariah, mudhârabah bentuk ini diaplikasikan pada tabungan dan deposito; kedua, mudhârabah muqayyadah, yaitu kenalikan dari jenis mudhârabah yang pertama. Dalam mudhârabah jenis ini, mudhârib terikat oleh pesyaratan yang diberkan oleh shâhib al-mâl di dalam meniagakan modal yang dipercayakan kepadanya. Persyaratan bisa berupa jenis usaha, tenggang waktu melakukan usaha, dan atau wilayah niaga. $^{28}$

\section{Analisis Kontruksi Akad Mudhârabah Dalam Fatwa Dewan Syariah Nasional-Majelis Ulama Indonesia (DSN-MUI) No: 03/DSN-MUI/IV/2000 Tentang Deposito}

Sumber hukum tidak tertulis dalam mengoperasikan perbankan syariah adalah fatwa DSNMUI. ${ }^{29}$ Keberadaan fatwa DSN-MUI semakin menunjukan perannya dalam merealisasikan pedoman pelaksanaan prinsip-prinsip syariah dalam perbankan syariah sejak diberlakukannya Undang-Undang Nomor 21 Tahun 2008 tentang Perbankan Syariah. Undang-undang Nomor 21 Tahun 2008 mewajiban para stakeholder untuk memerhatikan dan menyesuaikan kegiatan-kegiatan usaha sesuai dengan prinsip syariah yang tersebut dalam fatwa yang dikeluarkan oleh DSN-MUI. ${ }^{30}$ 


\section{Fastabiq: Jurnal Studi Islam}

ISSN 2723-0228

Volume 1 Nomor 1 Juni 2020

Salah satu fatwa yang dikeluarkan oleh DSN-MUI yang berpolakan investasi adalah fatwa Dewan Syari'ah Nasional No: 03/DSN-MUI/IV/2000 Tentang Deposito. Dalam fatwa tersebut dijelaskan bahwa Deposito yang dibenarkan, yaitu Deposito yang berdasarkan prinsip Mudharabah. Menurut Adiwarman Karim, ${ }^{31}$ dalam hal ini, bank syariah bertindak sebagai mudhârib (pengelola dana), sedangkan nasabah bertindak sebagai shâhib al-mâl (pemilik dana/investor). Dalam kapasitasnya sebagai mudhârib, bank syariah dapat melakukan berbagai macam usaha yang tidak bertentangan dengan prinsip syariah serta mengembangkannya, termasuk melakukan akad mudhârabah dengan pihak ketiga.

Dengan demikian, bank syariah dalam kapasitasnya sebagai mudhârib memiliki sifat sebagai wali amanah (trustee), yakni harus berhati-hati atau bijaksana serta beritikad baik dan bertanggung jawab atas segala sesuatu yang timbul akibat kesalahan atau kelalaiannya. Di samping itu, bank syariah juga bertindak sebagai kuasa dari usaha bisnis pemilik dana yang diharapkan dapat memperoleh keuntungan seoptimal mungkin tanpa melanggar berbagai aturan syariah. ${ }^{32}$

Senada dengan pendapat Adiwarman A Karim di atas, menurut Faaza Fakhurunnas, ${ }^{33}$ dalam produk perbankan syariah, nasabah akan mendepositokan dana di perbankan syariah dalam jangka waktu tertentu untuk di investasikan. Perjanjian produk deposito berjangka dengan akad mudhârabah pada umumnya memperkenankan bank syariah untuk menginvestasikan dana nasabah dalam skema investasi yang diinginkan. Dalam kegiatan investasi antara perbankan syariah dan nasabah yang membutuhkan dana, bank syariah juga dapat menggunakan akad-akad tertentu sesuai dengan karakteristik investasi termasuk akad mudhârabah. Hal ini memungkinkan bank syariah menggunakan model two tier mudhârabah yang berarti perbankan syariah melakukan dua tingkat akad mudhârabah dimana yang pertama adalah antara nasabah (shâhib al-mâl) dan bank syariah (mudhârib) dalam produk deposito berjangka dan yang kedua adalah antara bank syariah (dalam hal ini selain berkedudukan sebaga mudhârib pertama, bank syariah pun berkedudukan menjadi shâhib al-mân) dan nasabah yang membutuhkan dana untuk kegiatan bisnisnya (mudhârib kedua).

Dalam hal ini dibahas mengenai kedudukan para pihak (subjek akad) yang tercantum dalam fatwa MUI No. 03/DSNMUI/IV/2000 tentang Deposito. Dimana dalam ketentuan umumnya pada point 1 dan 2 yaitu "Dalam transaksi ini nasabah bertindak sebagai șāḥib al-māl atau pemilik dana, dan bank bertindak sebagai muḍārib atau pengelola dana. Dalam kapasitasnya sebagai muḍārib, bank dapat melakukan berbagai macam usaha yang tidak bertentangan dengan prinsip syari'ah dan mengembangkannya, termasuk di dalamnya mudarabah dengan pihak lain.

Yang perlu digarisbawahi dalam fatwa tersebut yaitu termasuk di dalamnya mudarabah dengan pihak lain. Berarti dapat ditarik kesimpulan bahwa ada banyak subjek dalam akad ini, yaitu nasabah pemilik modal atau deposan sebagai șāḥib al māl, bank sebagai muḍārib I, nasabah pemilik usaha sebagai muḍārib II.

Berdasarkan putusan fatwa DSN-MUI No. 03/DSN-MUI/IV/2000 tentang deposito yang telah disampaikan diatas, penulis memahami kedudukan pihak yang berakad sebagaimana yang tercantum dalam bagan diatas. Ketika Bank menginvestasikan dana nasabah deposan (șāḥib al-māl) secara mudarabah kepada pihak lain lalu siapakah yang berlaku atau berperan sebagai șāḥib al-māl dan 


\section{Fastabiq: Jurnal Studi Islam}

ISSN 2723-0228

Volume 1 Nomor 1 Juni 2020

apakah bank syariah bisa menjadi șāḥib al-māl?. Itulah pertanyaan-pertanyaan yang timbul setelah mengetahui fatwa DSN-MUI tersebut? Dan ini merupakan objek penelitian serta pembahasan dari penulis.

Dalam beberapa literatur fikih muamalah kontemporer, Wahbah al-Zuhaili menyebut skema akad mudhârabah bertingkat (dimana pihak mudhârib menginvestasikan kembali dengan akad mudhârbah atau semisalnya) dengan istilah al-mudhârib yudhârib. Rafiq Yunus al-Mishri menyebut dengan istilah al-mudhârib al-wasith, sedangkan Jaih Mubarok dan Hasanudin menyebut dengan istilah 'ulang mudhârabah'.

Menurut Jaih Mubarok dan Hasanudin, ${ }^{34}$ akad ulang mudhârabah merupakan salah satu topik yang menarik karena mencakup konsep ta'adi (melampaui batas/melakukan pekerjaan yang seharusnya tidak dilakukan) atas jenis usaha (termasuk akad) yang boleh atau tidak boleh dilakukan oleh mudhârib. Apakah mudhârib boleh melakukan akad ulang mudhârabah (berkedudukan sebagai shâhib al-mâl pada akad mudhârabah kedua)? Kalau tidak boleh, berarti mudhârib melakukan alta'adi. Kalau terjadi kerugian atau hilangnya modal usaha yang dilakukan mudhârib kedua, apakah mudhârib pertama harus bertanggung awab untuk menggantinya?

Pada saat penghimpunan dana, salah satunya menggunakan produk deposito, maka akad yang digunakan adalah akad mudhârabah. Nasabah penyimpanan dana berkedudukan sebagai shâhib al-mâl, sedangkan bank syariah berkedudukan sebagai mudhârib (pengelola). Kemudian dana tersebut (DPK) disalurkan oleh bank syariah kepada nasabah dengan akad mudhârabah. Bank syariah berkedudukan sebagai shâhib al-mâl, sedangkan nasabah (pengguna) berkedudukan sebagai mudhârib. Oleh karena itu, bank syariah memiliki dua kedudukan hukum, pertama sebagai mudhârib pada saat penghimpunan dana melalui produk depisoto, kedua berkedudukan sebagai shâhib al-mâl pada saat penyaluran dana (landing). Apakah hal tersebut di bolekan secara hukum?

Secara singkat, Rafiq Yunus al-Mishri menjelaskan bahwa ulama fikih sepakat bahwa pihak mudhârib tidak diperbolehkan untuk melakukan ulang mudhârabah atau menyerahkan dana milik shâhib al-mâl kepada pihak ketiga dengan skema akad mudhârabah, karena pihak shâhib al-mâl hanya mempercayakan dana tersebut kepada mudhârib, bukan kepada pihak ketiga. ${ }^{35}$

Wahbah al-Zuhaili ${ }^{36}$ menyampaikan dalam kitabnya al-Fiqh al-Islâmî wa adillatuh sejumlah ulama fikih berkaitan dengan boleh tidaknya mudhârib melakukan akad mudhârib yudhârib (ulang mudhârabah), yaitu sebagai berikut:

1. Menurut Ulama Hanafiyah, mudhârib tidak boleh melakukan ulang mudhârabah, kecuali jika pemilik modal memberikan kuasa (izin) kepadanya. Jika mudhârib memberikan modalnya kepada orang lain untuk mudhârabah ulang, sedangkan pemilik modal tidak memberikan izin, maka menurut Abu Hanifah modal tersebut tidak menjadi tanggungan mudhârib pertama dengan hanya adanya pemberian modal pada mudhârib kedua dan tidak pula dengan adanya kegiatan usaha dari mudhârib kedua dengan modal tersebut hingga dia memperoleh untung. Jika mudhârib kedua memperoleh untung, maka ketika itulah mudhârib pertama menanggungnya (menggantinya) pada pemilik modal. Adapun sebelum adanya keuntungan itu maka mudhârib pertama tidak menanggungnya. Oleh karena itu, jika modal rusak di 


\section{Fastabiq: Jurnal Studi Islam}

ISSN 2723-0228

Volume 1 Nomor 1 Juni 2020

tangan mudhârib kedua sebelum adanyanya keuntungan, maka kerusakan itu seperti rusaknya barang amanah orang lain.

Alasan pertama (sebelum adanya pekerjaan) adalah bahwa pemberian modal dari mudhârib pertama pada mudhârib kedua merupakan akad wadî'ah (titipan) darinya, karena dia memiliki hak menitipkan modal mudhârabah. Oleh karena itu, dia tidak menjadi tertanggung dengan adanya pemberian tersebut. Alasan kedua (setelah adanya pekerjaan) adalah bahwa pembrian modal dari mudhârib pertama pada mudhârib kedua itu adalah akad ibdha' dimana dia memiliki hak tersebut. Jika mudhârib kedua memperoleh keuntungan, maka ia menjadi bagian besama bagi mudharib pertama dalam modal tersebut. Hal itu menuntut mudhârib pertama untuk menanggung pada pemilik modal, sama seperti jika dia mencampurkan mudhârabah dengan yang lainnya.

Zufar berpendapat bahwa mudhârib pertama wajib menanggung modal dengan adanya pemberian modal tersebut, baik mudhârib kedua itu sudah bekerja maupun belum. Hal itu karena mudhârib pertama hanya memiliki hak memberikan modal dengan cara wadîah (titipan), sedangkan pemberian modal di sini dengan cara mudhârabah. Maka jika mudhârib pertama memberikan modal debfab cara mudhârabah, dia telah menyalahi (ketentuan akad mudhârabah) dengan pemberian modal tersebut. Oleh karena itu, dia wajib menjaminnya seperti wadi' (yang menerima titipan) jika dia menitipkan kembali kepada orang lain.

2. Pendapat selain Hanafiyah. Ulama Malikiyah berpendapat bahwa mudhârib wajib menjamin modal jika dia melakukan ulang mudhârabah tanpa izin pemilik modal, yaitu dengan cara memberikan modal itu kepada mudhârib kedua untuk akad mudhârabah karena kesewenangannya. Dalam hal ini keuntungannya diberikan kepada mudhârib kedua dan pemilik modal, sedangkan mudhârib pertama tidak berhak mendapat bagian keuntungan itu. Hal itu karena keuntungan dalam akad mudhârabah adalah seperti fee (upah dalam akad ju'âlah) yang tidak berhak diperoleh kecuali setelah pekerjaan selesai. Sementara itu mudhârib pertama ia tidak bekerja, maka ia tidak berhak mendapat bagian keuntungan. Mudhârib pertama wajib membayar tambahan keuntungan yang disyaratkan pada mudhârib kedua, yang berasal dari keuntungan yang didapat oleh mudhârib pertama dari pemilik modal. Sedangkan ulama Syafi'iyah berpendapat, dalam pendapat yang shahîin, bahwa mudhârib tidak boleh melakukan ulang mudhârabah pada pihak ketika untuk melakukan kerjasama bisnis dengannya dalam pekerjaan dan keutungan, sekalipun hal itu atas seizin pemilik modal. Dalam hal ini, mudhârabah yang terjadi dengan mudhârib pertama adalah sah, dan mudhârib kedua berhak mendapat ujrah mitsil (upah umum) dari mudhârib pertama jika dia telah bekerja.

Bahkan Imam al-Nawawi (salah seorang ulama bermazhab Syafi'i) menjelaskan bahwa:

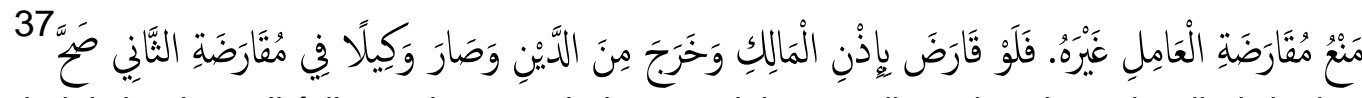
"Tidak boleh bagi mudhârib untuk menyalurkan modal yang dia terima kepada pihak ketiga sebagai modal. Apabila ia melakukan itu atas izin pemodal, tidak terhitung sebagai utang, dan 


\section{Fastabiq: Jurnal Studi Islam}

ISSN 2723-0228

Volume 1 Nomor 1 Juni 2020

dia hanya wakil untuk transaksi mudhârabah yang pertama, maka mudhârabah-nya sah secara hukum".

Lebih lanjut Imam al-Nawawi menjelaskan bahwa:

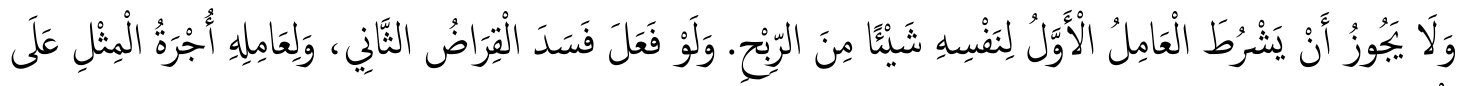

"mudhârib pertama tidak boleh mempersyaratkan, untuk mendapatkan keuntungan. Jika mudhârib pertama mempersyaratkan harus mendapatkan bagi hasil, maka mudhârabah yang kedua batal. Dan mudhârib pertama hanya berhak mendpaatkan ujrah mitsil (upah normal) dari pemilik modal".

Ulama Hanabilah diwakili oleh Ibn Qudamah al-Maqdisi menjelaskan sebagai berikut:

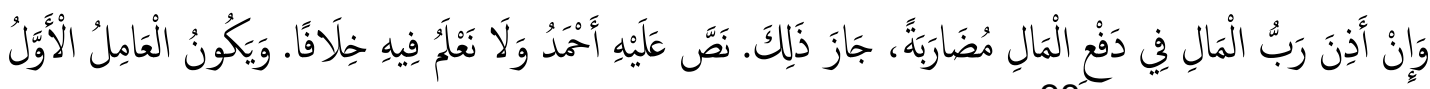

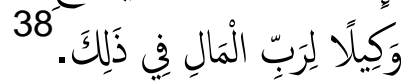

"Apabila pemilik modal memberikan izin menyerahkan modal mudhârabah kepada pihak ketiga, maka hal tersebut dibolehkan. Demikian yang ditegaskan oleh Imam A $\underline{h} m a d$, dan kami tidak mengetahui adanya khilâf (perbedaan pendapat) dalam hal ini. Dan posisi mudhârib pertama hanya sebagai wakil bagi pemodal dalam akad mudhârabah ini".

Lebih lanjut Ibn Qudamah al-Maqdisi menerangkan:

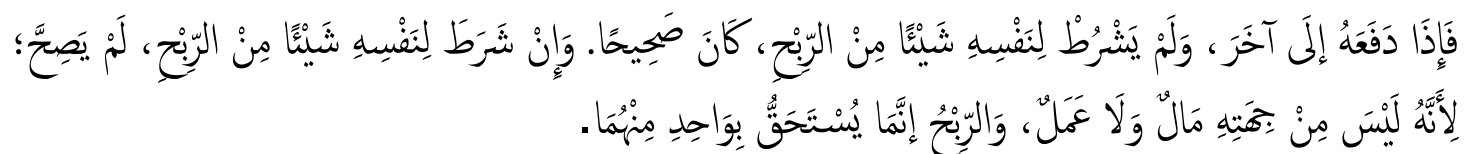

"Ketika mudhârib pertama menyerahkan modal itu kepada pihak ketiga, dan dia tidak mensyaratkan harus menerima bagi hasil, maka akad mudhârabah-nya sah. Namun jika mudhârib pertama mensyaratkan harus mendapatkan bagi hasil, maka mudhârabah-nya tidak sah. Karena dia bukan pemilik modal juga bukan pekerja. Sementara keuntungan hanya bisa didapatkan dengan salah satu dari dua sebab itu".

Dalam rangka menjelaskan peran Lembaga keuangan, baik bank syariah maupun BMT, terdapat dua topik pembahasan, antara lain sebagaimana dikemukakan oleh Wahbah al-Zuhaili sebagai berikut: ${ }^{39}$

1. Konsep kebiasaan (al-ma'rûf/al-'âdah), yaitu:

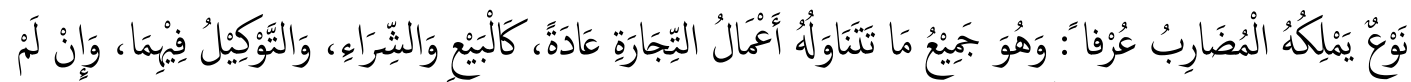

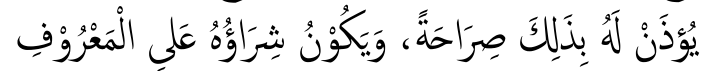

"Bentuk kegiatan yang dimiliki (berhak) dilakukan mudhârib berdasarkan kebiasan ('urf), yaitu semua perbuatan atau usaha bisnis (yang berhak dilakukan mudhârib berdasarkan pada kebiasaan, seperti melakukan penjualan, belanja, dan mewakilkan (untuk melakukan penjualan dan belanja), meskipun usaha yang dilakukannya tanpa izin yang jelas dari pemilik modal, maka belanja (usaha) yang dilakukannya atas dasar kebiasaan yang baik (alma'rûf)..."

2. Konsep mudhârabah mutlak, yaitu:

KONSTRUKSI AKAD MUDHÂRABAH DALAM FATWA DEWAN SYARIAH NASIONAL-MAJELIS ULAMA INDONESIA NOMOR: 03/DSN-MUI/IV/2000 TENTANG DEPOSITO

Panji Adam 


\section{Fastabiq: Jurnal Studi Islam}

ISSN 2723-0228

Volume 1 Nomor 1 Juni 2020

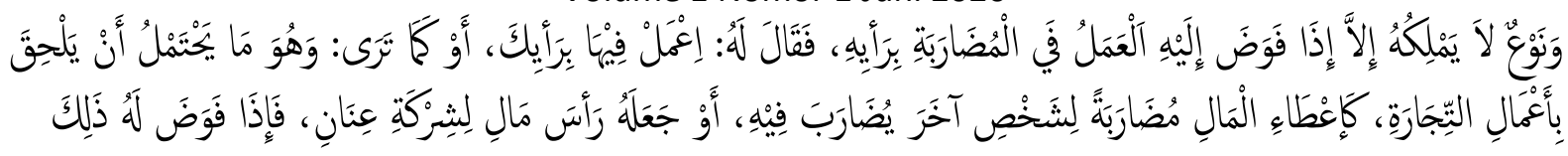

"Suatu usaha (termasuk akad) yang tidak menjadi milik mudhârib (mudhârib tidak berhak melakukannya) kecuali apabila pemodal menyerahkan modal kepada mudhârib secara mutlak (tanpa batasan), misalnya pemilik modal mengatakan: "Lakukanlah usaha dengan dengan pendapatmu atas berdasarkan analisismu". Perkataan tersebut mengandung pemberian keleluasaan kepada mudhârib untuk melakukan apa saja, termasuk melakukan akad ulang mudhârabah dengan pihak ketiga atau menjadikannya modal dalam akad syirkah-inan. Apabila akad mudhârabah bersifat mutlak, hukumnya adalah sah melakukan akad ulang mudhârabah".

Menurut Jaih Mubarok dan Hasanudin, berdasarkan dua konsep yang dikemukakan oleh Wahbah al-Zuhaili di atas, pada prinsipnya, merupakan dasar dibolehkannya akad ulang mudhârabah bagi Lembaga Keuangan Syariah, yaitu: ${ }^{40}$

1. Lembaga Keuangan Syariah (LKS) memiliki kegiatan berupa penghimpunan dana dan penyalurannya serta jasa. Oleh karena itu, Lembaga Keuangan Syariah, berdasarkan peraturan perundang-undangan serta adat atau al-urf, dibolehkan menghimpun dana masyarakat dengan menggunakan akad mudhârabah dan menyalurkannya juga boleh dengan akad mudhârabah. Dengan demikian, akad mudhârabah dalam penghimpunan dana terkandung izin (meskipun tidak dinyatakan secara eksplisit) bagi mudhârib yang membolehkannya melakukan akad ulang mudhârabah.

2. Akad mudhârabah yang dilakukan antar Lembaga Keuangan Syariah dan nasabah (penyimpan dana; dana pihak ketiga/DPK) seharusnya akad mudhârabah muthlaqah sehingga Lembaga Keungan Syariah dapat memilih akad secara leluasa dalam penyaluran dana, termasuk melakukan akad ulang mudhârabah.

Dengan demikian, penghimpunan dana berdasarkan pola deposito yang menggunakan akad mudhârabah, sebagaimana tertuang dalam fatwa Dewan Syari'ah Nasional No: 03/DSN-MUI/IV/2000 Tentang Deposito, berdasarkan pengamatan dan analisis penulis terhadap takyif fikih dan kontruksi akad dalam deposito syariah, maka penulis berpendapat bahwa akad yang digunakan dalam implmentasi Dewan Syari'ah Nasional No: 03/DSN-MUI/IV/2000 Tentang Deposito adalah akad mudhârib yudhârib atau ulang mudhârabah. Hal ini mengingat bahwa peran Lembaga Keuangan Syariah sebagai intermediary institution yang berfungsi menghimpun dana dari masyarakat serta menyalurkan dana kepada masyarakat.

\section{SIMPULAN}

Hasil penelitian menunjukan bahwa Fatwa Dewan Syari'ah Nasional No: 03/DSN-MUI/IV/2000 Tentang Deposito merupakan salah satu pedoman operasional bagi Lembaga Keuangan Syariah khsusnya bank syariah dalam menjalankan kegiatan usahanya. Bank sebagai intermediary institution 


\section{Fastabiq: Jurnal Studi Islam}

ISSN 2723-0228

Volume 1 Nomor 1 Juni 2020

mempunyai fungsi menghimpun dana masyarakat melalui simpanan berupa tabungan, giro dan deposito, serta menyalurkan kepada masyarakat melalui pembiayaan. Berdasarkan Fatwa Dewan Syari'ah Nasional No: 03/DSN-MUI/IV/2000 Tentang Deposito, bahwa akad yang digunakan dalam kegiatan tersebut menggunakan akad mudhârabah. Bank berperan sebagai pengelola modal (mudhârib) dan nasabah berperan sebagai investor (shâhib al-mâl). Dalam tataran implementasinya, pola akad mudhârabah kurang relevan digunakan apabila digunakan dalam produk deposito, mengingat fungsi bank adalah sebagai intermediary finance. Oleh karena itu, berdasarkan analisis penulis terhadap terhadap takyif fikih dan kontruksi akad dalam deposito syariah, maka penulis mendapat temuan bahwa akad yang digunakan dalam implmentasi Dewan Syari'ah Nasional No: 03/DSN-MUI/IV/2000 Tentang Deposito adalah akad mudhârib yudhârib; mudhârib al-wasîth atau biasa disebut juga ulang mudhârabah. Dalam hal ini pihak bank syariah selain berkedudukan sebagai mudhârib (pada akad mudhârabah pertama), bank syariah pun sekaligus berkedudukan sebagai shâhib al-mâl (pada akad mudhârabah kedua). Berdasarkan pendapat râjih (unggul) di antara para ulama, maka hukum melakukan akad mudhârabah bertingkat atau yang biasa disebut dengan istilah mudhârib yudhârib (ulang mudhârbah) adalah boleh berdasarkan 2 (dua) pertimbangan, yaitu pertimbangan urf/kebiasaan (dalam hal ini kebiasaan di lembaga keuangan syariah) dan konsep mudhârabah mutlak.

Bagi lembaga Keuangan Syariah, dalam menjalankan kegiatan usahanya haruslah berpedoman pada prinsip syariah khususnya bank syariah sebagaimana amanah Pasal 1 angka 12 Undang-Undang Nomor 21 Tahun 2008 tentang Perbankan Syariah; begitu pula bagi para akademisi agar melakukan penelitian lebih lanjut guna menghasikan temuan-temuan baru mengingat keterbatasan penulisan dalam mencari info serta referensi. 


\section{ENDNOTES}

Volume 1 Nomor 1 Juni 2020

${ }_{1}^{1}$ A. Wangsawidjaja Z, Pembiayaan Bank Syariah, Jakarta: Gramedia Pustaka Utama, 2012. Hal. 32.

2 Darsono-Ali Sakti, dkk, Dinamika Produk Dan Akad Keuangan Syariah DI Indonesia, Jakarta: PT RajaGrafindo Persada, 2019. Hal. 120-121.

${ }^{3}$ Moh. Mufid, Kaidah Fikih Ekonomi Dan Keuangan Kontemporer: Pendekatan Tematis dan Praktis, Jakarta: Kencana Prenada, 2019. Hal. 115.

4 Pambayun Setyo Palupi, Studi Analisis Terhadap Fatwa DSN-MUI No. 03/DSN MUI/IV/2000 Tentang Deposito, Az Zarqa', Vol. 7, No. 1, Juni 2015. Hal. 66.

${ }^{5}$ Soerjono Soekanto \& Sri Mamudji, Penelitian Hukum Normatif (Suatu Tinjauan Singkat), Jakarta: Rajawali Pers, 1985, hal. 15.

${ }^{6}$ Rianto Adi, Metode Penelitian Sosial dan Hukum, Jakarta: Granit, 2004, hal. 130.

${ }^{7}$ Khotibul Umam, Perbankan Syariah: Dasar-Dasar Dinamika Perkembangannya di Indonesia, Jakarta: PT RajaGrafindo Persada, 2016, hal. 95.

${ }^{8}$ Atang Abd Hakim. Fiqih Perbankan Syariah: Transformasi Fiqih Muamalah ke dalam Peraturan Perundang-Undangan, Bandung: Refika Aditama, 2011, hal. 218-219.

${ }^{9}$ Rachmadi Usman, Produk dan Akad Perbankan Syariah di Indonesia: Implementasi dan Aspek Hukum, Bandung: Citra Aditya Bakri, 2009, hal. 169.

${ }^{10}$ Khotibul Umam, Perbankan Syariah..., hal. 99.

${ }^{11}$ Dimyauddin Djuwaini, Fiqh Muamalah, Yogyakarta: Pustaka Pelajar, 2008, hal. 224.

${ }^{12}$ Muhamad, Manajemen Pembiayaan Mudharabah: Strategi Memaksimalkan Return dan Meminimalkan Risiko Pembiayaan Mudharabah di Bank Syariah, Bandung: PT Remaja Rosdakarya, 2019. Hal. 110.

${ }^{13}$ Neneng Nurhasanah, Mudharabah, Bandung: Refika Aditama, 2015, hal. 66.

${ }_{15}^{14}$ Rachamat Syafe'i, Fiqih Muamalah, Bandung: Pustaka Pelajar, 2001, hal. 224.

${ }^{15}$ Abd al-Rahman al-Jaziri, al-Fiqh alâal-Madzâhib al-Arba'ah, Kairo: Dâr al-Hadîts, 2004, Juz. III, hal. 32.

${ }^{16}$ Ibn 'Abidin, Hasyiyah Rad al-Mukhtâr 'alâ al-Dar al-Mukhtâr Syarh Tanwîr al-Abshâr Fiqh Abû Hanifah, Beirût: Dâr al-Fikr, 2000, Juz. VIII, hal. 277.

${ }_{17}^{17}$ Abd al-Rahman al-Jaziri, al-Fiqh alâal-Madzâhib..., hal. 35.

${ }^{18}$ Ibid., hal. 39.

${ }^{19}$ Ibid., hal. 37.

${ }^{20} \mathrm{M}$. Syafi'i Antonio, Bank Syari'ah dari Teori ke Praktik, Gema Insani Press, Jakarta, 2001. Hal. 95.

${ }^{21}$ Wabhah al-Zuhaili, al-Muâmalât al-Mâliyah al-Mu'âshirah, Beiurt: Dâr al-Fikr, 2002. Hal. 106.

${ }^{22}$ Wahbah al-Zuhhalili, al-Fiqh al-Islâmî wa Adillatuh, Beirût: Dâr al-Fikr, 2012, Juz. IV. Hal. 629.

${ }^{23}$ Ibn Majah Abu Abdullah Muhammad Ibn Yazid al-Quzwaini, Sunan Ibn Mâjah, Dâr al-Fikr, Beiût, 2008, Juz. I. Hal. 720.

${ }^{24}$ Wahbah al-Zuhaili, al-Fiqh al-Islâmî...., Hal. 630.

${ }^{25}$ Ibid. Hal. 631.

${ }^{26} \mathrm{Ibid}$. Hal. 631

${ }^{27} \mathrm{lbid}$. Hal. 635-637.

${ }^{28}$ Atang Abd Hakim. Fiqih Perbankan..., Hal. 215.

${ }^{29}$ Jaih Mubarok; Hasanudin; Yulizar D. Sanrego, Fatwa Tentang Hadiah Di Lembaga Keuangan Syariah, MIQOT Vol. XXXVII No. 2 Juli-Desember 2013. Hal. 332.

${ }^{30}$ Ahyar Ari Gayo; Ade Irawan Taufik, Kedudukan Fatwa Dewan Syariah Nasional Majelis Ulama Indonesia Dalam Mendorong Perkembangan Bisnis Syariah (Perspektif Hukum Perbankan Syariah), Jurnal Rechtsvinding Media Pembinaan Hukum Nasioal, Volume 1 Nomor 2 Agustus 2012. Hal. 268.

${ }^{31}$ Adiwarman A Karim. Bank Islam: Analisis Fiqih Dan Keuangan, Jakarta: PT RajaGrafindo Persada, 2004. Hal. 351.

${ }^{32}$ Ibid. Hal. 352.

${ }^{33}$ Faaza Fakhrunnas, Investasi Keuangan Syariah: Konsepsi dan Aplikasi, Ygyakarta: Ekonisa, 2019. Hal. 85-86.

${ }^{34}$ Jaih Mubarok dan Hasanudin, Fikih Mu'amalah Maliyyah: Akad Syirkah Dan Mudharabah, Bandung: Simbiosa, 2017. Hal. 192.

${ }^{35}$ Rafiq Yunus al-Mishri, Ushûl al-lqtishâd al-Islâmî, Damaskus: Dar al-Qalam, 2012. Hal. 251.

${ }^{36}$ Wahbah al-Zuhaili, al-Fiqh al-Islâmî...., Hal. 650-652. 
Fastabiq: Jurnal Studi Islam

ISSN 2723-0228

Volume 1 Nomor 1 Juni 2020

${ }^{37}$ Abu Zakariya Muhyi al-Din Yahya Ibn Syarif al-Nawawi, Raudhah al-Thâlibin wa 'Umdah al-Muftîn, Beirut: Maktabah al-Islâmî, 1991, juz. V. Hal. 132.

${ }^{38}$ Abu Muhammad Muwafiq al-Din Abdullah Ibn Ahmad Ibn Muhammad al-Maqdisi Ibn Qudamah alJama'ili al-Maqdisi al-Damasyqi al-Hanbali, al-Mughnî Li Ibn al-Qudâmah, Kairo: Maktabah alQâhirah, 1968, juz. V. Hal. 36.

${ }^{39}$ Wahbah al-Zuhaili, al-Fiqh al-Islâmî...., Hal.652.

40 Jaih Mubarok dan Hasanudin, Fikih Mu'amalah Maliyyah...Hal. 195. 


\section{REFERENSI}

Abidin, Ibn ,2000, Hasyiyah Rad al-Mukhtâr 'alâ al-Dar al-Mukhtâr Syarh Tanwîr al-Abshâr Fiqh Abû Hanifah. Beirût: Dâr al-Fikr.

Adi, Rianto, 2004, Metode Penelitian Sosial dan Hukum. Jakarta: Granit.

al-Hanbali, Abu Muhammad Muwafiq al-Din Abdullah Ibn Ahmad Ibn Muhammad al-Maqdisi Ibn Qudamah al-Jama'ili al-Maqdisi al-Damasyqi,1968, al-Mughnî Li Ibn al-Qudâmah. Kairo: Maktabah al-Qâhirah.

al-Jaziri, Abd al-Rahman, 2004, al-Fiqh alâal-Madzâhib al-Arba'ah, Kairo: Dâr al-Hadîts.

al-Mishri, Rafiq Yunus, 2012, Ushûl al-lqtishâd al-Islâmî. Damaskus: Dar al-Qalam.

al-Nawawi, Abu Zakariya Muhyi al-Din Yahya Ibn Syarif, 1991, Raudhah al-Thâlibin wa 'Umdah alMuftîn. Beirut: Maktabah al-Islâmî.

al-Quzwaini, Ibn Majah Abu Abdullah Muhammad Ibn Yazid, 2008, Sunan Ibn Mâjah. Dâr al-Fikr, Beiût.

al-Zunhaili, Wabhah, 2002, al-Muâmalât al-Mâliyah al-Mu'âshirah. Beiurt: Dâr al-Fikr.

al-Zuhalili, Wahbah, 2012, al-Fiqh al-Islâmî wa Adillatuh. Beirût: Dâr al-Fikr.

Antonio, M. Syafi'i, 2001, Bank Syari'ah dari Teori ke Praktik. Gema Insani Press, Jakarta.

Darsono-Ali Sakti, dkk, 2019, Dinamika Produk Dan Akad Keuangan Syariah DI Indonesia. Jakarta: PT RajaGrafindo Persada.

Djuwaini, Dimyauddin, 2008, Fiqh Muamalah. Yogyakarta: Pustaka Pelajar.

Fakhrunnas. Faaza, 2019, Investasi Keuangan Syariah: Konsepsi dan Aplikasi. Ygyakarta: Ekonisa.

Gayo, Ahyar Ari; Ade Irawan Taufik, "Kedudukan Fatwa Dewan Syariah Nasional Majelis Ulama Indonesia Dalam Mendorong Perkembangan Bisnis Syariah (Perspektif Hukum Perbankan Syariah"), Jurnal Rechtsvinding Media Pembinaan Hukum Nasioal, Vol. 1 Nomor 2 Agustus 2012.

Hakim, Atang Abd, 2011, Fiqih Perbankan Syariah: Transformasi Fiqih Muamalah ke dalam Peraturan Perundang-Undangan. Bandung: Refika Aditama.

Karim, Adiwarman A, 2004, Bank Islam: Analisis Fiqih Dan Keuangan. Jakarta: PT RajaGrafindo Persada.

Mubarok, Jaih; hasanudin; Yulizar D. Sanrego, "Fatwa Tentang Hadiah Di Lembaga Keuangan Syariah", MIQOT Vol. XXXVII No. 2 Juli-Desember 2013.

Mubarok, Jaih dan Hasanudin, 2017, Fikih Mu'amalah Maliyyah: Akad Syirkah Dan Mudharabah. Bandung: Simbiosa.

Mufid, Moh, 2019, Kaidah Fikih Ekonomi Dan Keuangan Kontemporer: Pendekatan Tematis dan Praktis. Jakarta: Kencana Prenada.

Muhamad, 2019. Manajemen Pembiayaan Mudharabah: Strategi Memaksimalkan Return dan Meminimalkan Risiko Pembiayaan Mudharabah di Bank Syariah, Bandung: PT Remaja Rosdakarya.

Nurhasanah, Neneng, 2015, Mudharabah. Bandung: Refika Aditama.

Palupi, Pambayun Setyo. "Studi Analisis Terhadap Fatwa DSN-MUI No. 03/DSN MUI/IV/2000 Tentang Deposito", Az Zarqa', Vol. 7, No. 1, Juni, 2015.

Soekanto, Soerjono \& Sri Mamudji, 1985, Penelitian Hukum Normatif (Suatu Tinjauan Singkat). Jakarta: Rajawali Pers.

Syafe'i, Rachamat, 2001, Fiqih Muamalah. Bandung: Pustaka Pelajar. 
Fastabiq: Jurnal Studi Islam

ISSN 2723-0228

Volume 1 Nomor 1 Juni 2020

Umam, Khotibul, 2016, Perbankan Syariah: Dasar-Dasar Dinamika Perkembangannya di Indonesia. Jakarta: PT RajaGrafindo Persada.

Usman, Rachmadi, 2009, Produk dan Akad Perbankan Syariah di Indonesia: Implementasi dan Aspek Hukum. Bandung: Citra Aditya Bakri.

Wangsawidjaja, A. Z, 2012, Pembiayaan Bank Syariah. Jakarta: Gramedia Pustaka Utama. 